\title{
The pathogenicity of the Streptococcus genus
}

\author{
W. Krzyściak • K. K. Pluskwa • A. Jurczak • D. Kościelniak
}

Received: 9 May 2013 / Accepted: 11 June 2013 / Published online: 3 July 2013

(C) The Author(s) 2013. This article is published with open access at Springerlink.com

\begin{abstract}
Streptococcus infections are still one of the important problems facing contemporary medicine. As the World Health Organization (WHO) warns, Streptococcus pneumoniae is responsible for the highest number of pneumonia cases all over the world. Despite an increasing number of pneumococcal vaccinations, incidences of disease connected to this pathogen's infection stay at the same level, which is related to a constantly increasing number of infections caused by nonvaccinal serotypes. Unfortunately, the pathogenicity of bacteria of the Streptococcus genus is also connected to species considered to be physiological flora in humans or animals and, additionally, new species exhibiting pathogenic potential have been discovered. This paper presents an opinion concerning the epidemiology of streptococci infections based on case studies and other publications devoted to this problem. It also sheds new light based on recent reports on the prevention of protective vaccinations application in the case of streptococci infections.
\end{abstract}

\section{Selected factors of the pathogenicity of streptococci described in this paper}

The term pathogenicity determinant refers to those features which determine the ability of a microorganism to cause a disease, but which are not themselves required for its survival [1]. Henderson et al. define pathogenicity determinants as pathogen components which cause damage in a host organism; this may include factors which are important for

W. Krzyściak $(\bowtie) \cdot$ K. K. Pluskwa

Department of Medical Diagnostics, Pharmacy Faculty, Jagiellonian University Medical College, 9 Medyczna St., 30-688 Krakow, Poland

e-mail: wirginiakrzysciak@cm-uj.krakow.pl

A. Jurczak · D. Kościelniak

Department of Pediatric Dentistry, Institute of Dentistry,

Jagiellonian University Medical College, Krakow, Poland pathogen survival [2]. These definitions, however, do not take into account the role of host susceptibility to infection; instead, they note only those features of the pathogen which are responsible for disease development. According to these definitions, only those organisms which cause diseases in healthy people are pathogens, while opportunistic or commensal microorganisms, which are only able to infect hosts with immune system disorders, are not considered to be pathogens.

Casadevall and Pirofski [3] proposed a new definition of pathogenicity and pathogenicity determinants for microorganisms which encompassed the state of a host's immunological defenses. The pathogenicity of a given microorganism was expressed as the degree of damage caused both by the microorganism itself and by the immune system in response to the pathogen.

One of the most invasive groups of bacteria is the Streptococcus genus. It is divided into 49 species and eight subspecies, from which as many as 35 have been identified as sources of invasive infections in humans. Microorganisms considered to be the cause of common infections include: $S$. pneumoniae, S. pyogenes - group A (group A Streptococcus, GAS), S. agalactiae - group B (group B Streptococcus, GBS), and $S$. mutans [4].

According to the estimations of the World Health Organization (WHO), about 1.2 million children aged below 5years die each year as a result of pneumonia, for which the main casual factor is $S$. pneumoniae, and this constitutes $18 \%$ of all deaths in this age group [5]. The high incidence of the above diseases and the mortality related to $S$. pneumoniae infections have prompted scientists to seek to develop vaccines aimed at reducing the incidence of such infections. It is known that the main factor underlying microorganism pathogenicity is the so-called polysaccharide envelope [6], which was the basis of the division of the $S$. pneumoniae microorganism into over 90 serotypes [7-9]. Seventeen immunogenic proteins have been identified on 
this microorganism surface, and the occurrence of 13 of them is dependent on the host age [4]. Polysaccharide antigens are used in anti-pneumococcal vaccines. They are conjugated in the vaccines with proteins in order to enhance the immunological response, i.e., with respect to that which would occur during natural infection by bacteria within the polysaccharide envelope [10]. Conjugation of these substances allows successful immunization of children before the second year of life, who are, at this age, a reservoir of numerous opportunistic pathogenic bacteria [8].

S. pneumoniae is characterized by significant genetic flexibility and, thus, is subject to natural transformations which allow it to obtain new phenotypic features. Recombinations occurring in this manner within the polysaccharide envelope enable the microorganism to circumvent the barrier formed by the host's immune system [4]. Therefore, numerous types of vaccines against $S$. pneumoniae have been created so far, and further research on bacterial strains has formed the basis for widening the list of antigens which may constitute a potential target for the activity of future generations of vaccines.

The next most common cause of diseases and mortality worldwide are invasive GAS infections. S. pyogenes are responsible for about 700 million infections per year, which result in the death of about 500,000 people [11]. One of the most common S. pyogenes strains is the strain M1T1, which is responsible for both pharyngitis and more severe conditions, such as necrotizing fasciitis or toxic shock syndrome. This bacteria is equipped with flagella referred to as antigen $\mathrm{T}$. However, unlike the flagella observed in S. pneumoniae, the presence of the flagella in $S$. pyogenes causes decreased invasiveness and pathogenicity of the strain. Despite the similarity of both kinds of flagella in general, i.e., the main genetic structure, fine differences in particular genes enable functional diversity between the encoded proteins. The flagella of the M1T1 strain increase the adhesive abilities of the proteins towards the endothelium; however, they concurrently constitute a molecular pattern for phagocytary cells of the host, and, thus, are subject to higher activity and faster elimination from an organism [12].

During a study conducted on S. pyogenes, 66 new proteins related to the cell membrane were identified for the first time on the surface of this microorganism, and as many as half of them are immunoreactive proteins and 23 are exposed on the cell surface [4]. Such huge differentiation of surface proteins enables wide-ranging research to be conducted on vaccines, the target of whose activity would be various kinds of antigens. One of the main factors of $S$. pyogenes pathogenicity is streptococcal pyrogenic exotoxin B (SpeB) of an activity of cysteine protease [4]. SpeB is formed by most GAS strains, and, therefore, any decrease in virulence may also be affected by an inhibition of $s p e B$ gene expression or by the chemical inactivation of the protein itself. Other factors affecting GAS virulence also include: streptolysin $\mathrm{O}$, protein $\mathrm{M}$, SpeA, or streptokinase, which are also targets of therapeutic activity during infections. Despite extensive studies on GAS, no licensed vaccine against this group of microorganisms has been created so far [11]. This is influenced, inter alia, by the large serotypic differentiation of protein $\mathrm{M}$, which was considered at the beginning of the 21 st century to offer the potential for vaccine applications $[4,11]$. A 6 -valent vaccine against GAS containing $\mathrm{N}$-end parts of six serotypes of protein $\mathrm{M}$ and tested on animals gave a desirable effect - an increase in the level of antibodies directed towards antigens contained within it. In the first stage of clinical trials, an increase in the number of antibodies was also demonstrated, and, additionally, no cross-reactions with human tissues were reported. The vaccine is the subject of further tests; however, a disadvantage attributed to it is its defense against only 6 of the 120 suggested serotypes of protein M [4]. The development of genetic research conducted on $S$. pyogenes may, in the future, allow an elaboration of methods which would identify antigens suitable for application in vaccines. Such research was performed in silico by Sharma et al. [11]. It resulted in the identification of the genes for 309 surface proteins, among which 260 present in at least 6 of the 8 examined strains were selected. Next, 147 proteins were selected for which it was possible to establish a topology on the microorganism cell surface, and their origin was determined. It appeared that many of these proteins are factors of S. pyogenes virulence. After an analysis of 81 of the 147 genes, it was demonstrated that $82 \%$ of them are present in all the examined GAS isolates, while 73 of them $(90.12 \%)$ occur in over $80 \%$ of the isolates. As a result, 52 proteins which may constitute the target of future vaccines were presented. Genetic research is accelerating the creation of a vaccine against GAS, since it considerably widens the list of surface antigens which may be used. Additionally, they confirm the occurrence of particular proteins on numerous bacterial strains, which may lead to successful worldwide application of vaccinations. The research also established that serotype M1 is less invasive compared to serotype M49; however, this requires confirmation via additional research [11].

GBS, S. agalactiae, has become an equally important microorganism which is responsible for miscarriages, and may also constitute a risk of premature birth and neonate infection in the form of sepsis, pneumonia, or meningitis. In the United States, GBS infection is diagnosed in about 5,000 neonates per year, and mortality caused by this microorganism is estimated at ca. $5 \%$.

Studies on $S$. agalactiae have provided information concerning 27 main surface proteins of this species. They include ornithine carbamoyltransferase (OCT) and protein PGK, which react with antigens directed against them. These proteins are the subject of scientific research aimed at their application during the creation of vaccines against GBS. The studies focused on GBS constitute a very important element allowing the development of methods for the prevention of 
diseases caused by this microorganism, since no commercial vaccine protecting against $S$. agalactiae infections has been created so far [4].

The pathogenicity of $S$. mutans is primarily related to the ability of adhesion to host cells. Biofilm formation is a complex process engaging a number of proteins. Khan et al. made a mutation of $S$. mutans, impairing the microorganism's ability to form biofilms. The modified strains were characterized by poorer adhesion to surfaces covered with saliva and by weakened biofilm formation. Confocal and scanning microscope images confirmed that the biofilm in these strains was thinner and looser compared to the biofilm formed by nonimpaired strains. Forty-four proteins, the expression of which is higher in a situation of proper biofilm formation, and 13 proteins of weakened expression were identified using electrophoretic techniques [13]. The described proteins relating to biofilm formation mainly include glycosyltransferases (Gtf), which mediate biofilm matrix synthesis, extracellular polysaccharides (EPS) [14, 15]. As observed by Flemming and Wingender, there is no biofilm without an EPS matrix [16]. The main components of EPS are glucans synthesized from saccharose, which provide the binding sites, and, thus, promote the accumulation of microorganisms and formation of cell clusters or microcolonies on the tooth surface. S. mutans produces at least three kinds of glycosyltransferases (Gtf): GtfB is related to insoluble glucan synthesis; GtfC synthesizes soluble and insoluble glucans; GtfD mainly synthesizes soluble glucans. According to Koo et al., GtfB and GtfC are essential for EPS matrix formation, with GtfB being mainly responsible for $S$. mutans aggregation [15] due to its high affinity to bacteria [17], GtfC is adsorbed on the tooth surface, while GtfD acts as a starter for GtfB [17]. Additionally, other surface proteins having an affinity to glucan (glucan-binding proteins, Gbps) contribute to biofilm growth by interactions of $S$. mutans with extracellular glucan. There are at least four groups of glucan-binding proteins, GbpsA, GbpsB, GbpsC, and GbpsD, differing in terms of their affinity to glucan, structure, and immunological properties. Duque et al. proved that GbpsB plays a role in biofilm formation [14]. A microorganism adhering to the enamel via glucan is the main saccharose-dependent way of biofilm formation, but there is also a saccharose-independent mechanism leading to biofilm formation [18]. Aggregation under conditions independent of saccharose is based on interactions between agglutinins present in saliva and P1 adhesins originating from S. mutans [18]. Agglutinins present in saliva contribute to the process of $S$. mutans adhesion and aggregation via interaction with antigen I/II, i.e., the multifunctional adhesin P1 (also called AgB, adhesin SpaP, or Pac1) embedded in bacteria cell walls and encoded by the spaP gene [13, 18-20].

The family of Ag I/II proteins represented, inter alia, by $\mathrm{SpaP}, \mathrm{SspA}$, or SspB proteins is identified not only on the surface of $S$. mutans but also on other microorganisms, such as Streptococcus pyogenes, Streptococcus agalactiae, or Streptococcus suis [19]. The genetic sequence encoding Ag I/II is composed of six separate regions. The most important of them include region $\mathrm{A}$ rich in alanine and region $\mathrm{P}$ rich in proline. Region $\mathrm{V}$, which concentrates most of the various sequences observed in particular strains, is localized between them. Regions A and V encode adhesive epitopes occurring on the surface of bacteria cells (so-called adhesintopes), which are responsible for a microorganism's affinity to saliva glycoproteins [21]. The contribution of regions A, P, and V in adhesion was confirmed in a study conducted using mutant strains [19]. None of them demonstrated the ability to adhere to solid surfaces covered with saliva membranes. The expression and biological activity of protein P1 in S. mutans also depends on numerous gene products, e.g., genes luxS, $\operatorname{rop} A$, and $\operatorname{srt} A$ (an encoding enzyme responsible for adhesin P1 attaching to cell walls) $[18,22]$.

Protein SpaP, and other proteins from the Ag I/II family, specifically interact with glycoprotein-340 (gp-340), which is present in saliva. It is interesting that gp-340 dissolved in the liquid phase of the saliva participates in bacterial cell aggregation and, thus, eradicates them from the oral cavity. However, when gp-340 is absorbed on the surface of the teeth or gums, it constitutes a receptor for surface bacterial adhesins initiating adhesion processes [18, 19]. The AgI/II family of proteins also participates in interactions between the microorganisms, e.g., Streptococcus gordonii and Porphyromonas gingivalis, as well as in the aggregation of cells lacking in gp-340 [19]. The key role in interactions between $S$. mutans and saliva agglutinins is played by the specific structure and localization of protein $\mathrm{P} 1$, as has been proved thanks to an application of this microorganism's mutant strains (spaP and $s r t A)$. It has additionally been demonstrated that the lack of the expression of genes encoding the sortase A enzyme (SrtA) results in not only an incorrect localization of adhesin $\mathrm{P} 1$, but also of other surface proteins, which is significant in the context of bacteria aggregation abilities [18].

The ability of $S$. mutans species bacteria to form biofilm is significant from a clinical point of view not only in the context of caries etiology, but also in cases of endocarditis (IE) [23]. IE development is possible when the formation of a very small clot rich in platelets and fibrinogen occurs as a result of slight damage to the endocardium. When microorganisms reach the blood at this time, they may use this favorable medium for embedding and biofilm formation. Such clots are formed most often at the edge of leaflets of the mitral and tricuspid valves at the side of the atrium, and on the aortic and pulmonary valves at the side of the ventricles [24]. The survival of $S$. mutans in the bloodstream, which it usually reaches after stomatological treatment, is connected to the presence of a few pathogenicity factors on the bacteria surface which have been described in various IE 
cases affected by this microorganism. Most importantly, there are those factors responsible for an increase in protein resistance to phagocytosis: a fibronectin-binding protein (socalled autolysin A, AtlA) [25] and a serotypically specific polysaccharide [26]. Next is antigen $C$, the expression of which results in an increased aggregation of blood platelets and, thus, increased coagulability [27].

The complexity of relationships between microorganisms and hosts, as well as the differentiated expression of the features determining microorganism pathogenicity, mean that pathogenicity is an unpredictable phenomenon. This is due to the fact that, even a complete understanding of both the hosts and the microorganisms does not allow a determination of all possible interactions between them.

Due to an occurrence of some special properties of the hosts and the microorganisms, different kinds of infectious disease varieties are observed more often. The possibilities offered by rapid worldwide travel contribute not only to microorganism transfer in environments not inhabited by them previously, but also enhance their virulence. We often need decades of research on all factors affecting the pathogenicity of microorganisms suspected of causing a given disease in order to link some diseases with their causes. Therefore, constant scientific interest in the interactions occurring between microorganisms and hosts may contribute to a deepening of knowledge concerning the pathogenicity of an increasing number of microorganisms [28].

\section{Pathogenicity of the Streptococcus genus}

Bacteria of the Streptococcus genus include a large number $(>100$ species) of microorganisms colonizing human and animal mucous membranes. They occur as physiological flora in the oral cavity and intestines of humans and animals. In addition, they often inhabit the skin, throat, and upper respiratory tract. However, numerous streptococci occur as opportunistic pathogens, causing infections in the case of weak immunological response of the host body they occupy. Pathogenic streptococci may be divided into three groups: those commonly causing infections in humans, and commensal and epizootic species which cause disease symptoms under specified conditions [4]. Typical pathogenic species include S. pneumoniae, with $S$. pyogenes and $S$. agalactiae. According to the estimations of the WHO, every year, pneumonia resulting mainly from $S$. pneumoniae activity causes ca. 1.2 million deaths of children younger than 5 years of age all over the world, which constitutes $18 \%$ of all deaths in this age group $[5,29] . S$. agalactiae (GBS) seems to be an equally dangerous microorganism. It is the most often the cause of invasive neonate infections, which occur in the form of sepsis, pneumonia ( $80 \%$ of cases), or, more rarely, meningitis (10\% of cases) or pyarthrosis. In $4 \%$ of cases, an infection ends with neonatal death. It is estimated that ca. 10-30\% of pregnant women are infected with GBS [30, 31]. An introduction of wide-scale prevention caused the frequency of early GBS sepsis occurrence in neonates to drop to 3-4 cases per 10,000 live births in 2010 [32]. Human physiological streptococci which are able to induce opportunistic infections include, e.g., S. mutans and $S$. intermedius. Species responsible for opportunistic, epizootic infections are $S$. canis (causing soft tissue infections, urinary tract infections, bacteremia, bone infections, pneumonia), species initially classified as $S$. bovis, especially including $S$. equinus, $S$. bovis (causing endocarditis, bacteremia, meningitis, sepsis) [4]. The consumption of infected milk resulted in some cases of human infections (such as arthritis, endocarditis, meningitis) with epizootic $S$. equi species, a zooepidemicus subspecies [33] (see Fig. 1).

\section{Streptococci inhabiting the oral cavity}

According to the latest reports, Streptococcus species normally observed in the oral cavity may be pathogenic. An example may be a case of healthy young men without risk factors, in whom spleen abscess and brain abscess caused by S. intermedius were diagnosed [39]. S. sanguis streptococci of the Viridans group were the reason for breast implant infection after wide-ranging stomatological treatment [40]. Over 60 cases in which S. salivarius was an etiological factor of meningitis as a result of iatrogenic infections have been recorded [41]. Oral cavity streptococci such as $S$. sanguinis, S. mitis, and S. gordonii were the reason for endocarditis [42-44]. The latest (isolated from the synovial membrane and synovial fluid of a 62-year-old man, and from the synovial membrane of a 78-year-old woman in the second case) was a reason for septic arthritis [45].

Despite the threats related to the above-mentioned bacteria, caries is the most common disease in children. It occurs

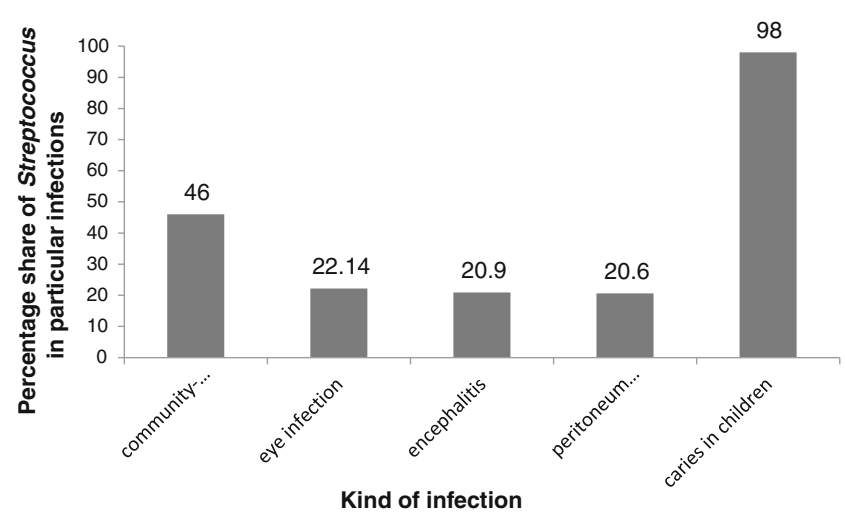

Fig. 1 Percentage Streptococcus contribution in particular infections. The diagram was prepared based on the studies of Fontán et al. [34], Bharathi et al. [35], Skoczyńska et al. [36], Juvén et al. [37], and Szczepańska et al. [38] 
five times more often than the second disease in the range, i.e., asthma [46]. In Poland, deciduous teeth caries concerns $35-50 \%$ of the children between the second and third years of life, and $56-60 \%$ of the children between the ages of 3 and 4 years. At the age of 6-7 years, deciduous teeth caries is observed in nearly $100 \%$ of children in Poland. Permanent teeth caries in Poland is noted in almost $90 \%$ of children aged 12 years [47]. In the United States, $50 \%$ of children aged 5-9 years have at least one cavity in the tooth or one filling caused by dental caries focus. This number increases up to $78 \%$ by the age of 17 years [46]. Despite numerous research on the etiology and development of the caries, scientists are still not concordant towards some aspects of this disease. Quite recently, S. mutans capable of biofilm formation in the oral cavity has been considered as the main factor causing caries [18, 48-51]. However, the fact that the presence of $S$. mutans alone is not sufficient to cause disease development has been the focus of increasing attention currently. The process of dental plaque formation and caries foci development involves, except for S. mutans, a few hundred other bacterial species, which, together, form the biofilm structure [17, 46, 52-54]. Except for microbiological factors, caries development also involves genetic, immunological, and environmental factors, including diet $[46,53]$. The species having the three main phenotypic features allowing them to survive in the oral cavity environment, i.e., ability of adhesion (and, thus, biofilm formation), ability of acids production, and ability of inhabiting an environment with large $\mathrm{pH}$ fluctuations, osmolarity or oxygen availability fluctuations, are considered as equally important species contributing to environment acidification and caries foci formation. These mainly include: S. sobrinus, $S$. mitis, Actinomyces spp., Lactobacillus spp., Bifidobacterium spp., and Fusobacterium nucleatum [46, 52, 55]. While considering the role of bacterial biofilm in the etiology of teeth and oral cavity diseases, it should be also noted that its occurrence is possible due to specific mutual interactions observed between microorganisms of the same or various species [46, 56]. Attention is focused on the examination of relations observed during biofilm formation and its maturation, development of resistance and wider spectrum of antibiotics, analysis of the microorganism's genome, and mechanisms of specific bacterial protein activity [57-59]. Despite an idea considering $S$. mutans as one of the main cariogenic factors has been abandoned recently, this microorganism is still the main target of scientific research.

S. mutans species may also cause endocarditis and bacteremia $[23,60]$. S. mutans was isolated from the heart valve in a patient with endocarditis, which had already been described in 1977 [61]. Oral cavity streptococci are correlated with observed endocarditis. This is an important issue from the point of view of the growing resistance to penicillin among oral cavity flora microorganisms (in the case of: $S$. mitis $>24 \% ; S$. sanguis $>19 \%$; S. mutans $>14 \%$ ) [62]. S. mutans was also a reason for recurring bacteremia in a woman with Sjögren's syndrome [63]. Besides endocarditis and bacteremia, $S$. mutans may also cause sepsis [40]. It is speculated that $S$. mutans may be the cause of other constitutional diseases [64]. Also, a rare case of retroperitoneal abscess caused by $S$. mutans has been described [65].

\section{Sepsis}

Streptococcus-caused sepsis is mainly related to severe $S$. pneumoniae and S. pyogenes infections. The frequency of invasive infections with $S$. pneumoniae in Poland is 0.78 cases per 100,000 people, while in children below 2 years of age, 5.17 cases are noted; the mortality rate as a result of these infections is $22.6 \%$ [66]. In total, 364 cases of pneumococci-caused diseases were noted in 2010, including sepsis (172 cases), encephalitis and/or meningitis (180 cases), and other, unspecified diseases (63 cases) [67]. In the same year, S. pneumoniae was the etiological factor of meningitis in children up to the fourth year of life, and encephalitis in $19.3 \%$ of the patients [68]. In Europe, the frequency of invasive $S$. pneumoniae infections range, depending on the country, from 0.4 to 20 cases per 100,000 people [69]. In the United States, 6.3 cases per 100,000 people are noted in the population below 18 years of age [70]. Such high incidence of the above-mentioned diseases and mortality related to $S$. pneumoniae infections have prompted scientists to an elaboration of vaccines aimed at decreasing the number of incidents. It is known that the main factor of microorganism pathogenicity is the polysaccharide envelope [48], which was the basis of division for over 90 serotypes of the microorganism S. pneumoniae [7-9]. Polysaccharide antigens are used in pneumococcal vaccine and are conjugated with proteins in order to enhance immunological response with respect to those which would have been observed during natural infection with bacteria within the polysaccharide envelope [10]. Conjugation of these substances allows an effective immunization of children below 2 years of age, who are a reservoir of numerous opportunistic pathogenic bacteria as this stage of their lives [8]. Many types of S. pneumoniae vaccines are distinguished; however, 7-, 10-, and 23-valent vaccines are used the most often. 7valent vaccine (protein conjugate vaccine, PCV7) contains polysaccharide antigens which were found in seven serotypes of the microorganisms responsible for $80-95 \%$ of invasive pneumococcal infections [49]. Its effectiveness is confirmed by the data collected after the vaccine introduction in the United States - the number of cases of invasive pneumococcal disease among children up to the 5 th year of age decreased by $94 \%$ [71]. However, PCV7 does not provide a homogenous effect for all vaccinal serotypes 
which it is aimed at. Comparing infections from the period before and after 7-valent vaccine introduction in the United States, the highest decrease in occurrence (three-fold and more) was noted for serotypes 14, 9V, and 23F. A two-fold decrease in the frequency of occurrence was observed for serotypes $18 \mathrm{C}$ and $6 \mathrm{~B}$, while the lowest decrease was noted for serotype 19F. The number of infections caused by nonvaccinal serotypes was to be concurrently increasing.

Similar trends were observed in the case of strains resistant to antibacterial substances. At the moment of vaccines introduction, resistance among vaccinal serotypes decreased about 1.5 -fold, while the resistance of nonvaccinal serotypes was doubled. An increase in the number of noninvasive serotypes resistant to two or more antimicrobial factors was also observed [7]. Poland introduced PCV7 to the vaccinations schedule in 2008 , together with 22 other countries. In turn, 10valent vaccine obtained pre-qualification from the WHO in 2010 [8]. It may be concluded from the official data, that the number of people vaccinated against pneumococci in Poland increased from 148,664 in 2009 to 155,258 in 2010 . Despite this, incidences of disease related to this pathogen infection have not decreased [68].

Conjugated 13-valent vaccine (PCV13) of widened spectrum of activity has been created as a response to an increasing number of infections caused by nonvaccinal serotypes [8]. It is composed, except for antigens used in PCV7, of six additional polysaccharide antigens characterizing further S. pneumoniae serotypes, and they were combined with the same membrane protein, CRM197. These serotypes have been observed most often in Africa, Asia, and Latin America, and are consistent with serotypes causing $70 \%$ of invasive pneumococcal infections all over the world. It was also demonstrated during the research that PCV13 may also be used in children infected with the human immunodeficiency virus (HIV) virus, which, to a certain extent, protected them against pneumococcal infections. The 13 -valent vaccine was introduced in over 40 countries; however, there is still a lack of documentation related to this vaccine's influence on the spread of infections caused by $S$. pneumoniae around the world, confirming a decrease in cases caused by $S$. pneumoniae serotypes used in the vaccine [8].

Vaccine against $S$. pneumoniae targeted towards the highest number of serotypes of this microorganism is polysaccharide 23-valent vaccine (PPV23). It demonstrated weak immunogenicity towards children; however. it gained wide application in risk groups and among older people [9]. This polysaccharide vaccine is not conjugated with protein, and, therefore, should not be administered in children less than years of age, and it has been recommended since 2000 that PPV23 should follow PCV7 vaccination [6].

Investigators suggest [9] that S. pneumoniae serotypes such as $11 \mathrm{~A}, 31,10 \mathrm{~A}$, and $9 \mathrm{~N}$ should be treated in a prioritized manner in the creation of new vaccines against this pathogen, since they are responsible for the highest number of infections caused by nonvaccinal serotypes.

The next significant reason for diseases occurrence and mortality all over the world is invasive GAS infections. $S$. pyogenes is responsible for ca. 700 million infections each year, causing about 500,000 deaths [11]. In Europe, they are noted with varying frequencies per 100,000 people: 3.12 cases in Great Britain [72]; 3.1 in France [73]; as much as 3.9 in Finland [74]. The mortality rate as a result of GAS infection in these countries is 19,14 , and $9 \%$, respectively. In the United States, the frequency of invasive GAS infections is similar: 3.5 cases per 100,000 people, with a mortality rate of $12.5 \%$ [75] (see Fig. 2). GAS strains are concurrently responsible for ca. 18 million cases of rheumatic heart
Fig. 2 Number of cases of invasive pneumococcal disease caused by Streptococcus pneumoniae over the years in Europe, using Denmark as an example. The diagram was prepared based on the studies of Harboe et al. [76] and Ingels et al. [77]

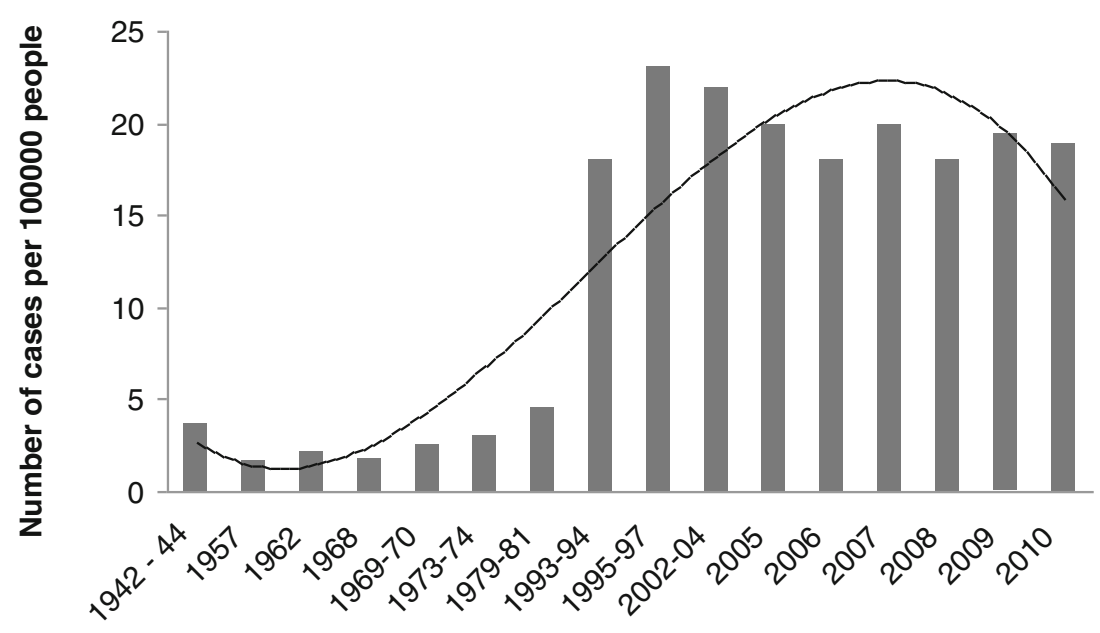




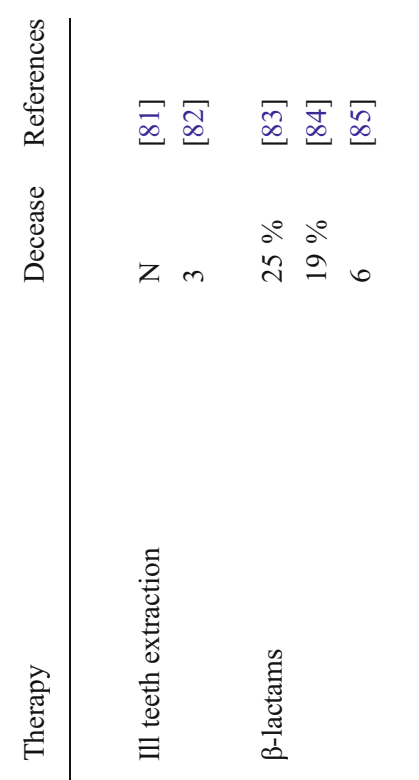

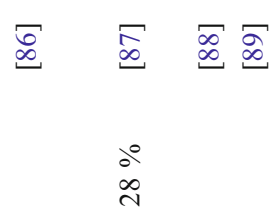

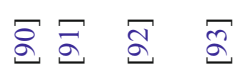

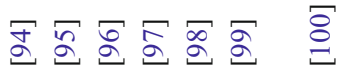

z z
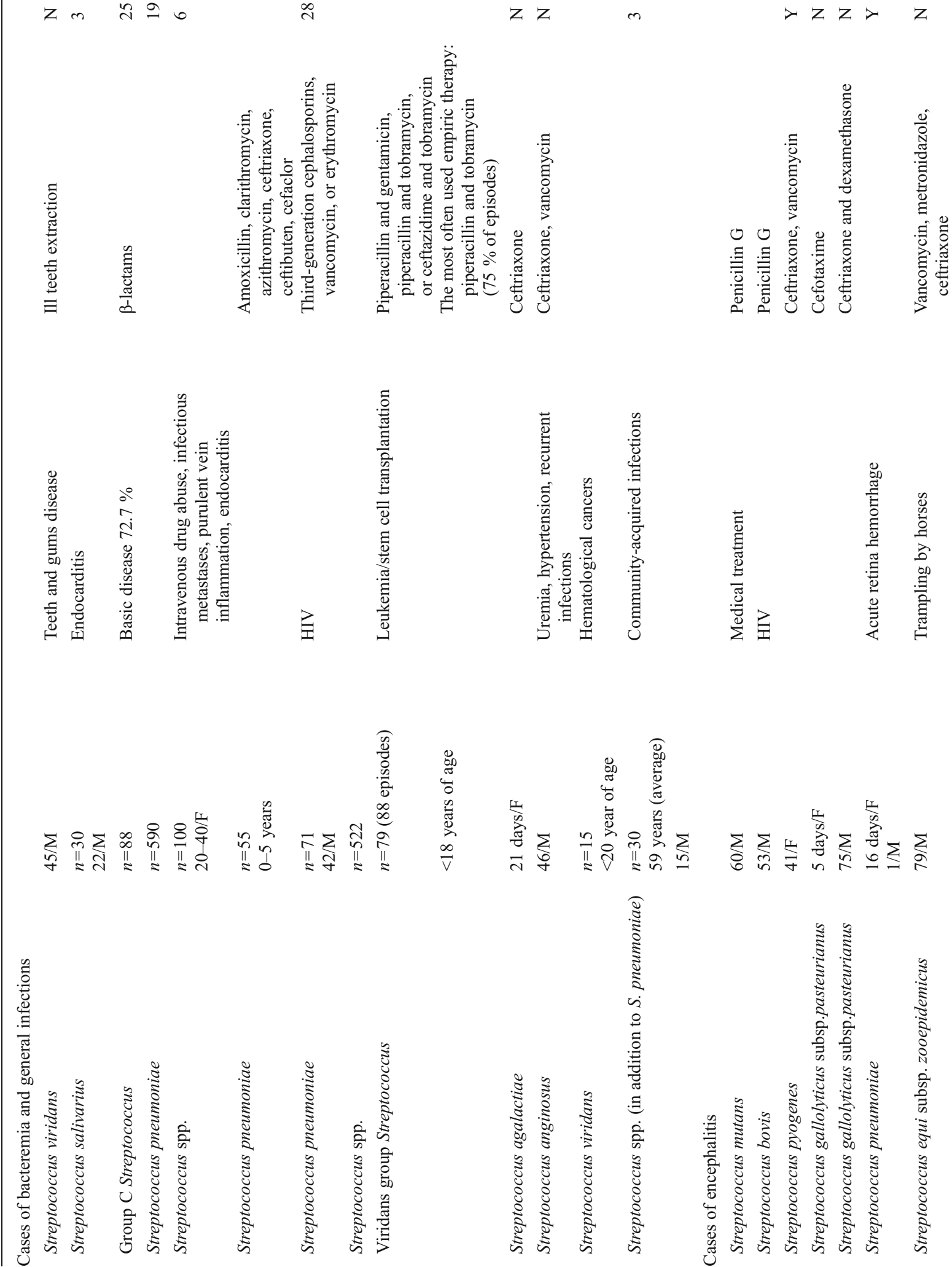


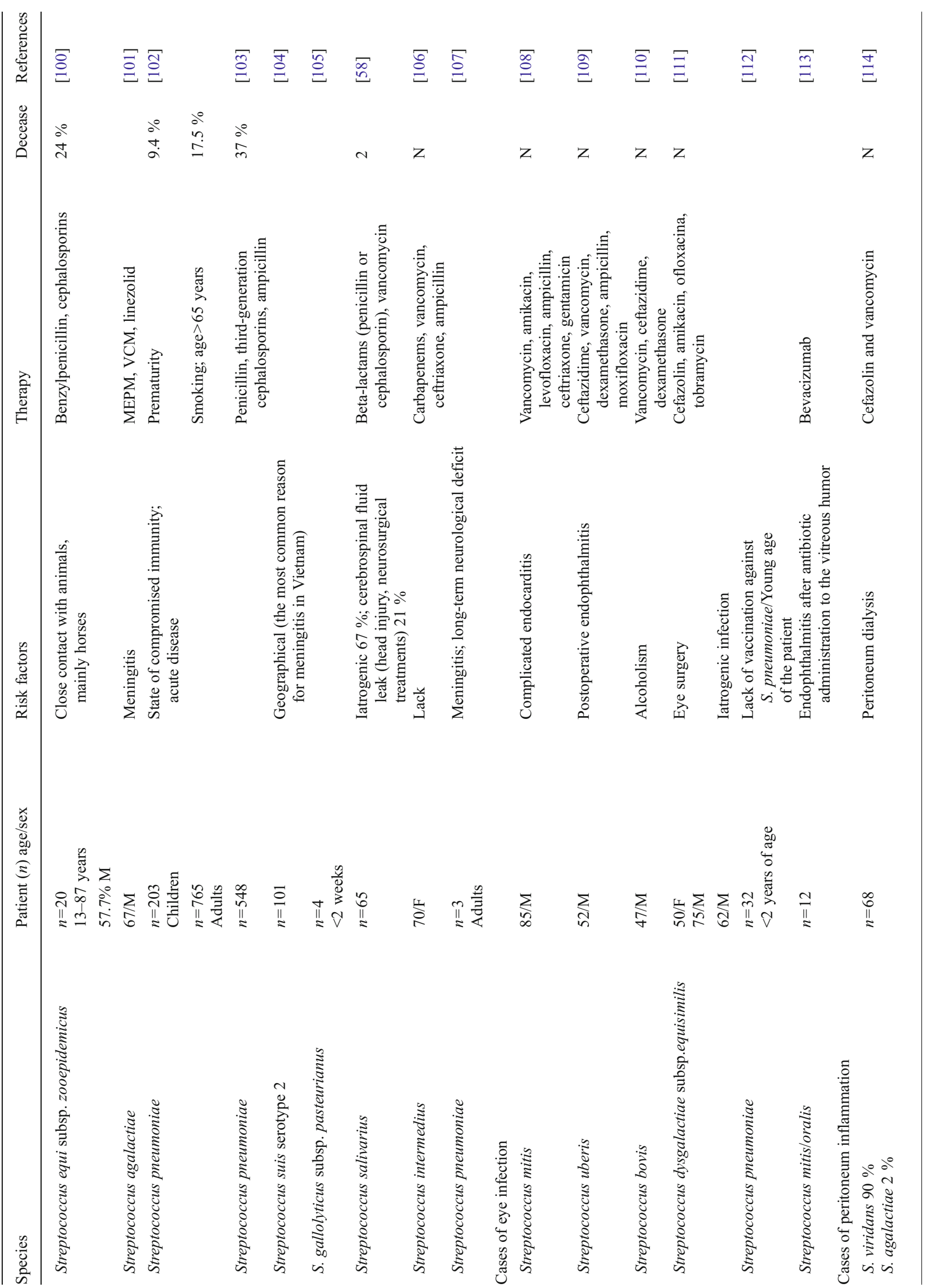




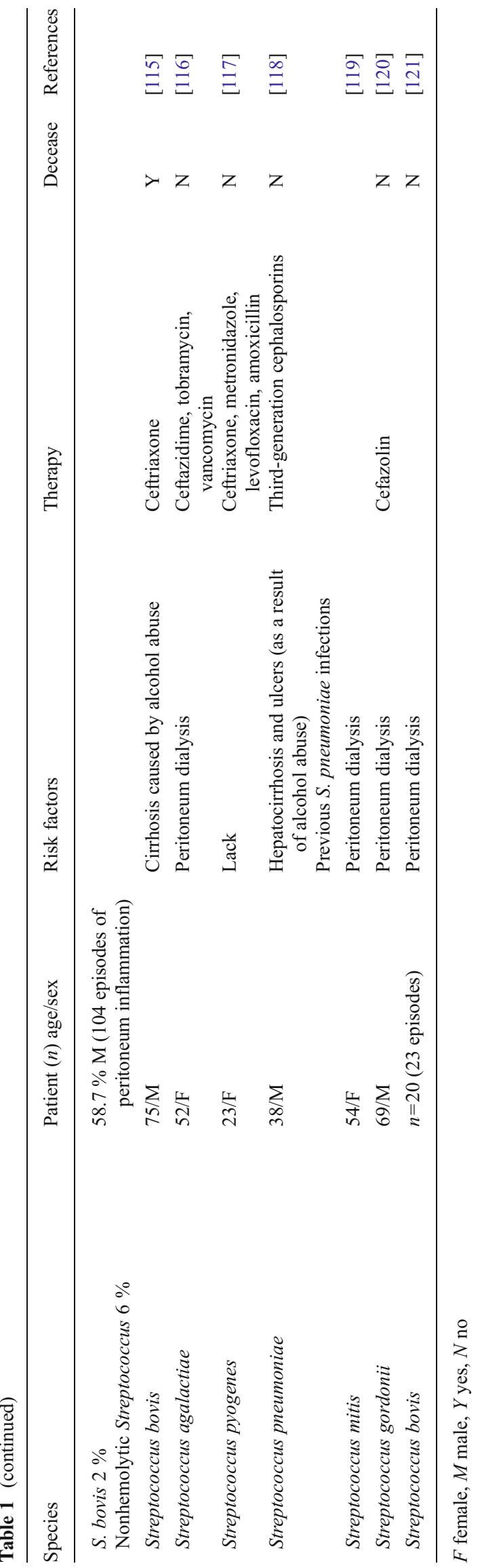

disease. resulting in a death of ca. 500,000 people each year. A considerable relationship between GAS strains causing pharyngitis in children and the strains related to invasive disease in society was also observed. These data suggest that schoolchildren may constitute a reservoir of infections for society [78-80].

One of the most common $S$. pyogenes strains is M1T1, which is responsible both for pharyngitis and more severe states, such as necrotizing fasciitis or toxic shock syndrome. This bacterium is equipped with flagella referred to as antigen T. However, unlike in the case of flagella noted in S. pneumoniae, their presence in $S$. pyogenes causes a decrease in the invasiveness and pathogenicity of the strain. Despite the similarity of both kinds of flagella in general and their main genetic structure, small differences in particular genes enable functional diversity of encoded proteins. The flagella of M1T1 strains increase the adhesive properties of bacteria towards the endothelial tissue; however, they concurrently constitute molecular standards for phagocytic cells of the host, and, thus, are exposed by their increased activity and faster elimination from an organism [12] (see Table 1).

Despite the wide range of GAS-related research, no licensed vaccine against this group of microorganisms has been created so far [11]. This is affected by, e.g., large serotype differentiation of protein $\mathrm{M}$, which was the hope for an application in vaccines at the beginning of the 21 st century $[4,11]$. A formulated 6 -valent vaccine against GAS containing $\mathrm{N}$-end parts of six serotypes of protein $\mathrm{M}$ provided a desirable effect in tests on animals - an increase in the antibodies index against antigens contained within it. An increase in the antibodies index was also demonstrated in the initial phase of clinical studies, and, additionally, no cross-reactions with human tissues were observed. The vaccine is subject to further tests; however, it is considered that its disadvantage is protection against only 6 among 120 suggested serotypes of protein M [4]. The development of genetic studies conducted on S. pyogenes may, in the future, allow to elaborate on the methods which will help identify antigens suitable for application in vaccines. Such research has been conducted in silico [11]. The result was an identification of genes for 309 surface proteins, among which at least 260 were present in 6 among the 8 examined strains that were selected. Subsequently, 147 proteins for which it was possible to establish the topology on the microorganism cell surface were selected, and their origin was established. It appeared that many of these proteins constitute the virulence factor of $S$. pyogenes. The analysis of 81 among 147 genes demonstrated that $82 \%$ of them were present in all the examined GAS isolates, while 73 of 


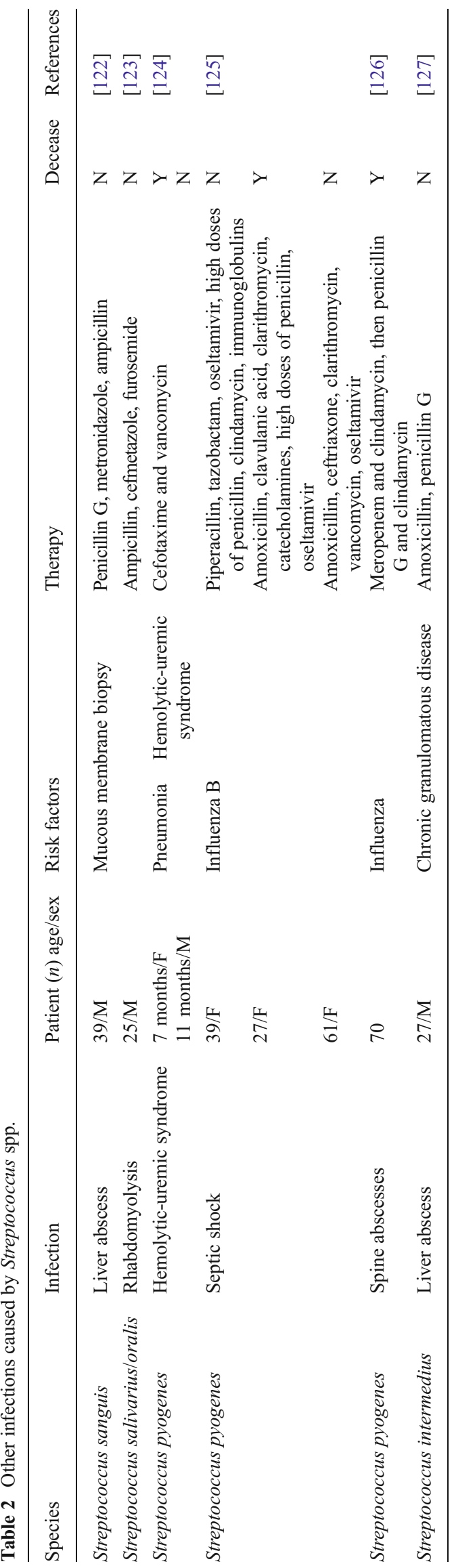

them $(90.12 \%)$ were noted in over $80 \%$ of isolates. As a result, 52 proteins which may constitute a target for future research have been presented. Genetic examination is an approach for the creation of vaccine against GAS, since they considerably widen the list of surface antigens which may be used for the process. Additionally, they confirm an occurrence of particular proteins in numerous bacterial strains, which may point towards the success of vaccinations all over the world. It was also established, as a result of the studies conducted, that serotype M1 is less invasive than M49; however, this needs to be verified by additional research [11] (see Tables 1 and 2).

\section{New species}

Pathogenic species of the Streptococcus genus were isolated and described as early as by the end of the 19 th century [128, 129]. Subsequently, new species have been discovered and described: Hardie and Whiley in 1997 reported about ca. 40 species [130]; 10 years later, ca. 50 species were known, and most of them were pathogenic for humans [4]. Certainly, this number is not definitive. An example is $S$. tigurinus, a species discovered this year by Swiss researchers, and present in the oral cavity as physiological flora; however, it may be responsible for endocarditis and meningitis [131]. Another example is a new subspecies of $S$. gallolyticus identified in 2003, i.e., pasteurianus [132], described for the first time as an etiological factor of meningitis in an infant in 2009 (see Table 1) and in an adult in 2010 (see Table 1). Another species is $S$. urinalis - a case of bacteremia caused by this pathogen [133] was described in a 60-year-old man with urethral stricture history. S. australis, described initially as one of the oral streptococci [134], also appeared to be an etiological factor in the case of meningitis [135]. An example of the species responsible for a range of human and animal infections (responsible for the spontaneous fermentation of dairy products in Africa) was $S$. infantarius subsp. infantarius (Sii) belonging to $S$. bovis/S. equinus, exhibiting $80 \%$ similarity to the $S$. thermophilus genome [136].

\section{Summary}

Infections with bacteria of the Streptococcus genus play a significant role from a clinical point of view. Firstly, the infections are of varying character, from local to severe general infections (see Tables 1 and 2). Secondly, the pathogenicity of the Streptococcus genus is 
connected not only to "classical" pathogens, but cases of opportunistic infections are also described more often, e.g., species physiologically inhabiting the oral cavity ( $S$. intermedius, S. salivarius), where injuries or surgical treatments may cause infections, and, worryingly, cases of meningitis caused by $S$. intermedius without previous risk factors have been reported [39]. Additionally, streptococci are identified as one of the main etiological factors of such severe diseases like pneumonia, meningitis, or peritoneum inflammation, and also diseases of a social character, like caries (see Fig. 1). Caries appears to be a huge problem and, unfortunately, there is a lack of suitable knowledge in the society concerning risk factors (see Table 3), which results in $87 \%$ of caries in children in Poland alone [148]. Comparing the results of CDL indices in 12-year-old children for European countries, Poland is placed in the next to last position $(\mathrm{CDL}=4.4)$, the best dentition state is noted for children in Holland $(\mathrm{CDL}=0.9)$, while the highest index was noted in Latvia $(\mathrm{CDL}=7.7)$ [47]. In the United States, $50 \%$ of children aged 5-9 years have at least one cavity in their teeth [46].

Due to long-term research which has broadened the scientific understanding of the virulence of specific pathogens, scientists are able to create new vaccines, which are oriented toward specific substances or antigens occurring on the surface of given microorganisms. This allows increased effectiveness in the fight against infections caused by, e.g., S. pneumoniae. The Centers for Disease Control and Prevention (CDC), WHO, and National Institute of Hygiene, Poland (PZH) reports reveal that the number of people vaccinated against pneumococci has being increasing (in Poland, it grows each year-from 2007 to 2011, the number of those vaccinated increased by as much as 78,500) [5, 32, 149]. This points to increased awareness within society and the application of pneumococcal infections prophylaxis. Despite this, morbidity-related infections caused by this pathogen are not decreasing, and this is connected to the new and pressing problem faced by the medical world, i.e., the growing number of dangerous nonvaccine strains causing an increasing number of infections in humans [7].

In the light of new taxonomic reports, differentiation of the increasingly growing number of species and subspecies, as well as the latest descriptions of cases of particular species of Streptococcus infections, the pathogenicity connected to the Streptococcus genus is still not fully recognized and should be the subject of further studies.

Table 3 Caries in children caused by Streptococcus spp.

\begin{tabular}{|c|c|c|c|}
\hline Species & Patient $(n)$ age/sex & Risk factors & References \\
\hline S. mutans & $\begin{array}{l}n=133 \\
1-4 \text { years }\end{array}$ & $\begin{array}{l}\text { Falling asleep with a bottle } \\
\text { Improper hygiene of the oral cavity }\end{array}$ & [137] \\
\hline S. mutans & $\begin{array}{l}n=3531 \\
4-11 \text { years }\end{array}$ & Passive smoking & {$[138]$} \\
\hline S. mutans & Children $<3$ years & $\begin{array}{l}\text { Vertical and horizontal transmission } \\
\text { Frequent meals consumption, pulpy } \\
\text { consistence of meals } \\
\text { Improper nutrition of pregnant mother } \\
\text { Early appearance of teeth weaken saliva } \\
\text { secretion, composition of saliva different } \\
\text { to in adults }\end{array}$ & [139] \\
\hline S. mutans & $n=156$ mother-infant pairs & Caesarean section & {$[140]$} \\
\hline S. mutans & $\begin{array}{l}n=109 \\
3 \text { years }\end{array}$ & Caesarean section & [141] \\
\hline S. mutans and Lactobacillus spp. & Children $<6$ years & $\begin{array}{l}\text { Vertical and horizontal transmission } \\
\text { Frequent consumption of sugars }\end{array}$ & [142] \\
\hline S. mutans & Children & $\begin{array}{l}\text { Transmission in early period of life } \\
\text { Dietary factors }\end{array}$ & [143] \\
\hline S. mutans and S. sobrinus & $\begin{array}{l}n=54 \\
2.5 \text { years }\end{array}$ & S. mutans and S. sobrinus in mother & {$[144]$} \\
\hline S. mutans and S. sobrinus & $\begin{array}{l}n=30 \\
\text { Children }\end{array}$ & $\begin{array}{l}\text { "Sticky desserts" } \\
\text { Higher socioeconomic status (data from Sudan) }\end{array}$ & {$[145]$} \\
\hline S. mutans & $1-6$ years & S. mutans in mother & [146] \\
\hline Streptococci from Streptococcus mutans group & & Psychosocial, behavioral factors & {$[147]$} \\
\hline
\end{tabular}


Conflict of interest All authors confirm that there is no conflict of interest.

Open Access This article is distributed under the terms of the Creative Commons Attribution License which permits any use, distribution, and reproduction in any medium, provided the original author(s) and the source are credited.

\section{References}

1. Sørensen UB, Poulsen K, Ghezzo C, Margarit I, Kilian M (2010) Emergence and global dissemination of host-specific Streptococcus agalactiae clones. MBio 24(3):e00178-10

2. Henderson B, Poole S, Wilson M (1996) Bacterial modulins: a novel class of virulence factors which cause host tissue pathology by inducing cytokine synthesis. Microbiol Rev 60(2):316-341

3. Casadevall A, Pirofski LA (1999) Host-pathogen interactions: redefining the basic concepts of virulence and pathogenicity. Infect Immun 67(8):3703-3713

4. Cole JN, Henningham A, Gillen CM, Ramachandran V, Walker MJ (2008) Human pathogenic streptococcal proteomics and vaccine development. Proteomics Clin Appl 2(3):387-410

5. World Health Organization (WHO) (2013) Weekly epidemiological record, vol. 88, pp 117-128

6. Sanders ME, Taylor S, Tullos N, Norcross EW, Moore QC 3rd, Thompson H, King LB, Marquart ME (2013) Passive immunization with Pneumovax ${ }^{\circledR} 23$ and pneumolysin in combination with vancomycin for pneumococcal endophthalmitis. BMC Ophthalmol 13:8

7. Mera R, Miller LA, Fritsche TR, Jones RN (2008) Serotype replacement and multiple resistance in Streptococcus pneumoniae after the introduction of the conjugate pneumococcal vaccine. Microb Drug Resist 14(2):101-107

8. Jefferies JM, Macdonald E, Faust SN, Clarke SC (2011) 13-valent pneumococcal conjugate vaccine (PCV13). Hum Vaccine 7(10):1012-1018, Epub 2011

9. Van Hoek AJ, Andrews N, Waight PA, George R, Miller E (2012) Effect of serotype on focus and mortality of invasive pneumococcal disease: coverage of different vaccines and insight into nonvaccine serotypes. PLoS One 7(7):e39150, Epub 2012

10. Bucholc B, Górska P, Janaszek-Seydlitz W (2011) Liczba wykonanych szczepień a układ odpornościowy. Przegl Epidemiol 65:629-634

11. Sharma A, Arya DK, Sagar V, Bergmann R, Chhatwal GS, Johri AK (2013) Identification of potential universal vaccine candidates against group A Streptococcus by using high throughput in silico and proteomics approach. J Proteome Res 12(1):336-346, Epub 2012

12. Crotty Alexander LE, Maisey HC, Timmer AM, Rooijakkers SH, Gallo RL, von Köckritz-Blickwede M, Nizet V (2010) M1T1 group A streptococcal pili promote epithelial colonization but diminish systemic virulence through neutrophil extracellular entrapment. J Mol Med (Berl) 88(4):371-381, Epub 2009

13. Khan AU, Islam B, Khan SN, Akram M (2011) A proteomic approach for exploring biofilm in Streptococcus mutans. Bioinformation 5(10):440-445

14. Duque C, Stipp RN, Wang B, Smith DJ, Höfling JF, Kuramitsu HK, Duncan MJ, Mattos-Graner RO (2011) Downregulation of $\mathrm{GbpB}$, a component of the VicRK regulon, affects biofilm formation and cell surface characteristics of Streptococcus mutans. Infect Immun 79(2):786-796

15. Koo H, Xiao J, Klein MI, Jeon JG (2010) Exopolysaccharides produced by Streptococcus mutans glucosyltransferases modulate the establishment of microcolonies within multispecies biofilms. J Bacteriol 192(12):3024-3032
16. Flemming HC, Wingender J (2010) The biofilm matrix. Nat Rev Microbiol 8(9):623-633

17. Bowen WH, Koo H (2011) Biology of Streptococcus mutansderived glucosyltransferases: role In extracellular matrix formation of cariogenic biofilms. Caries Res 45(1):69-86

18. Ahn SJ, Ahn SJ, Wen ZT, Brady LJ, Burne RA (2008) Characteristics of biofilm formation by Streptococcus mutans in the presence of saliva. Infect Immun 76(9):4259-4268

19. Brady LJ, Maddocks SE, Larson MR, Forsgren N, Persson K, Deivanayagam CC, Jenkinson HF (2010) The changing faces of Streptococcus antigen I/II polypeptide family adhesins. Mol Microbiol 77(2):276-286

20. Wen ZT, Yates D, Ahn SJ, Burne RA (2010) Biofilm formation and virulence expression by Streptococcus mutans are altered when grown in dual-species model. BMC Microbiol 10:111

21. Esberg A, Löfgren-Burström A, Ohman U, Strömberg N (2012) Host and bacterial phenotype variation in adhesion of Streptococcus mutans to matched human hosts. Infect Immun 80(11):3869-3879

22. Crowley PJ, Seifert TB, Isoda R, van Tilburg M, Oli MW, Robinette RA, McArthur WP, Bleiweis AS, Brady LJ (2008) Requirements for surface expression and function of adhesin P1 from Streptococcus mutans. Infect Immun 76(6):2456-2468

23. Jung CJ, Yeh CY, Shun CT, Hsu RB, Cheng HW, Lin CS, Chia JS (2012) Platelets enhance biofilm formation and resistance of endocarditis-inducing streptococci on the injured heart valve. J Infect Dis 205(7):1066-1075

24. Habib G, Hoen B, Tornos P, Thuny F, Prendergast B, Vilacosta I, Moreillon P, de Jesus Antunes M, Thilen U, Lekakis J, Lengyel M, Müller L, Naber CK, Nihoyannopoulos P, Moritz A, Zamorano JL; ESC Committee for Practice Guidelines (2009) Guidelines on the prevention, diagnosis, and treatment of infective endocarditis (new version 2009): the Task Force on the Prevention, Diagnosis, and Treatment of Infective Endocarditis of the European Society of Cardiology (ESC). Endorsed by the European Society of Clinical Microbiology and Infectious Diseases (ESCMID) and the International Society of Chemotherapy (ISC) for Infection and Cancer. Eur Heart J 30(19):2369-2413

25. Jung CJ, Zheng QH, Shieh YH, Lin CS, Chia JS (2009) Streptococcus mutans autolysin AtlA is a fibronectin-binding protein and contributes to bacterial survival in the bloodstream and virulence for infective endocarditis. Mol Microbiol 74(4):888-902

26. Nakano K, Ooshima T (2009) Serotype classification of Streptococcus mutans and its detection outside the oral cavity. Future Microbiol 4:891-902

27. Matsumoto-Nakano M, Tsuji M, Inagaki S, Fujita K, Nagayama K, Nomura R, Ooshima T (2009) Contribution of cell surface protein antigen c of Streptococcus mutans to platelet aggregation. Oral Microbiol Immunol 24:427-430

28. Casadevall A, Fang FC, Pirofski LA (2011) Microbial virulence as an emergent property: consequences and opportunities. PLoS Pathog 7(7):e1002136, Epub 2011

29. Black RE, Cousens S, Johnson HL, Lawn JE, Rudan I, Bassani DG, Jha P, Campbell H, Walker CF, Cibulskis R, Eisele T, Liu L, Mathers C; Child Health Epidemiology Reference Group of WHO and UNICEF (2010) Global, regional, and national causes of child mortality in 2008: a systematic analysis. Lancet 375(9730):1969-87

30. Brzychczy-Włoch M, Gosiewski T, Pawlik D, Szumała-Kakol A, Samead A, Heczko PB (2012) Occurrence of the hypervirulent ST-17 clone of Streptococcus agalactiae in pregnant women and newborns. Przegl Epidemiol 66(3):395-401

31. Szwabowicz K, Panasiuk A (2012) Carrier-state of group B streptococcus in pregnant women-performance standards. Przegl Epidemiol 66(1):33-38

32. Verani JR, McGee L, Schrag SJ; Division of Bacterial Diseases, National Center for Immunization and Respiratory Diseases, Centers for Disease Control and Prevention (CDC) (2010) Prevention of 
perinatal group B streptococcal disease - revised guidelines from CDC, 2010. MMWR Morb Mortal Wkly Rep 59(RR-10):1-36

33. Edwards AT, Roulson M, Ironside MJ (1988) A milk-borne outbreak of serious infection due to Streptococcus zooepidemicus (Lancefield Group C). Epidemiol Infect 101(1):43-51

34. Fontán MP, Cambre HD, Rodríguez-Carmona A, Muñiz AL, Falcón TG (2009) Treatment of peritoneal dialysis-related peritonitis with ciprofloxacin monotherapy: clinical outcomes and bacterial susceptibility over two decades. Perit Dial Int 29(3):310-318

35. Bharathi MJ, Ramakrishnan R, Shivakumar C, Meenakshi R, Lionalraj D (2010) Etiology and antibacterial susceptibility pattern of community-acquired bacterial ocular infections in a tertiary eye care hospital in south India. Indian J Ophthalmol 58(6):497-507

36. Skoczyńska A, Kriz P, Konradsen HB, Hryniewicz W (2000) Characteristics of the major etiologic agents of bacterial meningitis isolated in Poland in 1997-1998. Microb Drug Resist 6:147-153

37. Juvén T, Mertsola J, Waris M, Leinonen M, Meurman O, Roivainen M, Eskola J, Saikku P, Ruuskanen O (2000) Etiology of community-acquired pneumonia in 254 hospitalized children. Pediatr Infect Dis J 19(4):293-298

38. Szczepańska J, Lubowiecka-Gontarek B, Pawłowska E, Szydłowska-Walendowska B (2008) Czynniki ryzyka próchnicy związane z żywieniem a liczebność bakterii próchnicotwórczych w ślinie dzieci w wieku 3 lat. Dent Med Probl 45(2):156-164

39. Maliyil J, Caire W, Nair R, Bridges D (2011) Splenic abscess and multiple brain abscesses caused by Streptococcus intermedius in a young healthy man. Proc (Bayl Univ Med Cent) 24(3):195-199

40. Chang J, Lee GW (2011) Late hematogenous bacterial infections of breast implants: two case reports of unique bacterial infections. Ann Plast Surg 67(1):14-16

41. Wilson M, Martin R, Walk ST, Young C, Grossman S, McKean EL, Aronoff DM (2012) Clinical and laboratory features of Streptococcus salivarius meningitis: a case report and literature review. Clin Med Res 10(1):15-25

42. Chen L, Ge X, Wang X, Patel JR, Xu P (2012) SpxA1 involved in hydrogen peroxide production, stress tolerance and endocarditis virulence in Streptococcus sanguinis. PLoS One 7(6):e40034, Epub 2012

43. Matsui $N$, Ito $M$, Kuramae $H$, Inukai $T$, Sakai A, Okugawa $M$ (2013) Infective endocarditis caused by multidrug-resistant Streptococcus mitis in a combined immunocompromised patient: an autopsy case report. J Infect Chemother 19(2):321-325

44. Takahashi Y, Takashima E, Shimazu K, Yagishita H, Aoba T, Konishi K (2006) Contribution of sialic acid-binding adhesin to pathogenesis of experimental endocarditis caused by Streptococcus gordonii DL1. Infect Immun 74(1):740-743

45. Yombi JC, Belkhir L, Jonckheere S, Wilmes D, Cornu O, Vandercam B, Rodriguez-Villalobos H (2012) Streptococcus gordonii septic arthritis: two cases and review of literature. BMC Infect Dis 12:215. doi:10.1186/1471-2334-12-215

46. Peterson SN, Snesrud E, Liu J, Ong AC, Kilian M, Schork NJ, Bretz W (2013) The dental plaque microbiome in health and disease. PLoS One 8(3): e58487

47. Pawka B, Dreher P, Herda J, Szwiec I, Krasicka M (2010) Próchnica zębów u dzieci problemem społecznym. Probl Hig Epidemiol 91(1):5-7

48. Lehner T, Challacombe SJ, Caldwell J (1975) Immunological and bacteriological basis for vaccination against dental caries in rhesus monkeys. Nature 254:517-520

49. Loesche WJ (1986) Role of Streptococcus mutans in human dental decay. Microbiol Rev 50:353-380

50. Cvitkovitch DG, Li YH, Ellen RP (2003) Quorum sensing and biofilm formation in streptococcal infections. J Clin Investig 112:1626-1632

51. Ahn SJ, Burne RA (2007) Effects of oxygen on biofilm formation and the AtlA autolysin of Streptococcus mutans. J Bacteriol 189(17):6293-6302
52. Zijnge V, van Leeuwen MB, Degener JE, Abbas F, Thurnheer T, Gmür R, Harmsen HJ (2010) Oral biofilm architecture on natural teeth. PLoS One 5(2):9321

53. Kang MS, Oh JS, Lee HC, Lim HS, Lee SW, Yang KH, Choi NK, Kim SM (2011) Inhibitory effect of Lactobacillus reuteri on periodontopathic and cariogenic bacteria. J Microbiol 49(2):193199, Epub 2011

54. Wang W, Tao R, Tong Z, Ding Y, Kuang R, Zhai S, Liu J, Ni L (2012) Effect of a novel antimicrobial peptide chrysophsin-1 on oral pathogens and Streptococcus mutans biofilms. Peptides 33(2):212-219, Epub 2012

55. Redanz S, Standar K, Podbielski A, Kreikemeyer B (2011) A fivespecies transcriptome array for oral mixed-biofilm studies. PLoS One 6(12):e27827, Epub 2011

56. Ogawa A, Furukawa S, Fujita S, Mitobe J, Kawarai T, Narisawa N, Sekizuka T, Kuroda M, Ochiai K, Ogihara H, Kosono S, Yoneda S, Watanabe H, Morinaga Y, Uematsu H, Senpuku H (2011) Inhibition of Streptococcus mutans biofilm formation by Streptococcus salivarius FruA. Appl Environ Microbiol 77(5):1572-1580

57. Costa MT, Dorta ML, Ribeiro-Dias F, Pimenta FC (2012) Biofilms of black tooth stains: PCR analysis reveals presence of Streptococcus mutans. Braz Dent J 23(5):555-558

58. Kim do K, Kim KH, Cho EJ, Joo SJ, Chung JM, Son BY, Yum JH, Kim YM, Kwon HJ, Kim BW, Kim TH, Lee EW (2013) Gene cloning and characterization of MdeA, a novel multidrug efflux pump in Streptococcus mutans. J Microbiol Biotechnol 23(3):430-435

59. Koyanagi S, Lévesque CM (2013) Characterization of a Streptococcus mutans intergenic region containing a small toxic peptide and its cis-encoded antisense small RNA antitoxin. PLoS One 8(1):e54291, Epub 2013

60. Nakano K, Nomura R, Nakagawa I, Hamada S, Ooshima T (2004) Demonstration of Streptococcus mutans with a cell wall polysaccharide specific to a new serotype, $\mathrm{k}$, in the human oral cavity. $\mathrm{J}$ Clin Microbiol 42(1):198-202

61. McGhie D, Hutchison JG, Nye F, Ball AP (1977) Infective endocarditis caused by Streptococcus mutans. Br Heart J 39(4):456-458

62. Pasquantonio G, Condò S, Cerroni L, Bikiqu L, Nicoletti M, Prenna M, Ripa S (2012) Antibacterial activity of various antibiotics against oral streptococci isolated in the oral cavity. Int $\mathrm{J}$ Immunopathol Pharmacol 25(3):805-809

63. Nomura R, Hamada M, Nakano K, Nemoto H, Fujimoto K, Ooshima T (2007) Repeated bacteraemia caused by Streptococcus mutans in a patient with Sjogren's syndrome. J Med Microbiol 56(Pt 7):988-992

64. Nakano K, Nomura R, Matsumoto M, Ooshima T (2010) Roles of oral bacteria in cardiovascular diseases - from molecular mechanisms to clinical cases: cell-surface structures of novel serotype $\mathrm{k}$ Streptococcus mutans strains and their correlation to virulence. J Pharmacol Sci 113(2):120-125

65. Ioannidis O, Kakoutis E, Katsifa H, Rafail S, Chatzopoulos S, Kotronis A, Makrantonakis N (2011) Streptococcus mutans: a rare cause of retroperitoneal abscess. Adv Med Sci 56(1):113-118

66. Skoczyńska A, Kuch A, Gołebiewska A, Waśko I, Ronkiewicz P, Markowska M, Hryniewicz W (2011) Invasive pneumococcal disease in Poland in 2010. Pol Merkur Lekarski 31(182):80-85

67. Zieliński A, Czarkowski MP (2012) Choroby zakaźne w Polsce w 2010 roku. Przegl Epidemiol 66:175-184

68. Parda N, Polkowska A (2012) Zapalenia opon mózgowordzeniowych i zapalenia mózgu w Polsce w 2010 roku. Przegl Epidemiol 66:221-228

69. Pebody RG, Hellenbrand W, D'Ancona F, Ruutu P; European Union funded Pnc-EURO contributing group (2006) Pneumococcal disease surveillance in Europe. Euro Surveill 11(9):171-178

70. Li ST, Tancredi DJ (2010) Empyema hospitalizations increased in US children despite pneumococcal conjugate vaccine. Pediatrics 125(1):26-33 
71. Centers for Disease Control and Prevention (CDC) (2005) Direct and indirect effects of routine vaccination of children with 7valent pneumococcal conjugate vaccine on incidence of invasive pneumococcal disease-United States, 1998-2003. MMWR Morb Mortal Wkly Rep 54:893-897

72. Lamagni TL, Neal S, Keshishian C, Alhaddad N, George R, Duckworth G, Vuopio-Varkila J, Efstratiou A (2008) Severe Streptococcus pyogenes infections, United Kingdom, 20032004. Emerg Infect Dis 14(2):202-209

73. Lepoutre A, Doloy A, Bidet P, Leblond A, Perrocheau A, Bingen E, Trieu-Cuot P, Bouvet A, Poyart C, Lévy-Bruhl D; Microbiologists of the Epibac Network (2011) Epidemiology of invasive Streptococcus pyogenes infections in France in 2007. J Clin Microbiol 49(12):4094-4100

74. Siljander T, Lyytikäinen O, Vähäkuopus S, Snellman M, Jalava J, Vuopio J (2010) Epidemiology, outcome and emm types of invasive group A streptococcal infections in Finland. Eur J Clin Microbiol Infect Dis 29(10):1229-35. doi:10.1007/s10096-010-0989-9

75. O'Brien KL, Beall B, Barrett NL, Cieslak PR, Reingold A, Farley MM, Danila R, Zell ER, Facklam R, Schwartz B, Schuchat A (2002) Epidemiology of invasive group A streptococcus disease in the United States, 1995-1999. Clin Infect Dis 35(3):268-276

76. Harboe ZB, Benfield TL, Valentiner-Branth P, Hjuler T, Lambertsen L, Kaltoft M, Krogfelt K, Slotved HC, Christensen JJ, Konradsen HB (2010) Temporal trends in invasive pneumococcal disease and pneumococcal serotypes over 7 decades. Clin Infect Dis 50(3):329-337

77. Ingels H, Rasmussen J, Andersen PH, Harboe ZB, Glismann S, Konradsen H, Hoffmann S, Valentiner-Branth P, Lambertsen L; Danish Pneumococcal Surveillance Collaboration Group 20092010 (2012) Impact of pneumococcal vaccination in Denmark during the first 3 years after PCV introduction in the childhood immunization programme. Vaccine 30(26):3944-3950

78. Cockerill FR 3rd, MacDonald KL, Thompson RL, Roberson F, Kohner PC, Besser-Wiek J, Manahan JM, Musser JM, Schlievert PM, Talbot J, Frankfort B, Steckelberg JM, Wilson WR, Osterholm MT (1997) An outbreak of invasive group A streptococcal disease associated with high carriage rates of the invasive clone among school-aged children. JAMA 277(1):38-43

79. Haukness HA, Tanz RR, Thomson RB Jr, Pierry DK, Kaplan EL, Beall B, Johnson D, Hoe NP, Musser JM, Shulman ST (2002) The heterogeneity of endemic community pediatric group A streptococcal pharyngeal isolates and their relationship to invasive isolates. J Infect Dis 185(7):915-920, Epub 2002

80. Shulman ST, Bisno AL, Clegg HW, Gerber MA, Kaplan EL, Lee G, Martin JM, Van Beneden C (2012) Clinical practice guideline for the diagnosis and management of group A streptococcal pharyngitis: 2012 update by the Infectious Diseases Society of America. Clin Infect Dis 55(10):1279-1282. doi:10.1093/cid/cis847

81. McPhedran H (1923) Case of Streptococcus viridans bacteriaemia with endocarditis and apparent recovery. Can Med Assoc J 13(9):669-670

82. Ruoff KL, Miller SI, Garner CV, Ferraro MJ, Calderwood SB (1989) Bacteremia with Streptococcus bovis and Streptococcus salivarius: clinical correlates of more accurate identification of isolates. J Clin Microbiol 27(2):305-308

83. Bradley SF, Gordon JJ, Baumgartner DD, Marasco WA, Kauffman CA (1991) Group C streptococcal bacteremia: analysis of 88 cases. Rev Infect Dis 13(2):270-280

84. Plouffe JF, Breiman RF, Facklam RR (1996) Bacteremia with Streptococcus pneumoniae. Implications for therapy and prevention. Franklin County Pneumonia Study Group. JAMA 275(3):194-198

85. Bernaldo de Quirós JC, Moreno S, Cercenado E, Diaz D, Berenguer J, Miralles P, Catalán P, Bouza E (1997) Group A streptococcal bacteremia. A 10-year prospective study. Medicine (Baltimore) 76(4):238-248

86. Tarallo L, Tancredi F, Schito G, Marchese A, Bella A; Italian Pneumonet Group (Società Italiana Pediatria and Associazione Italiana Studio Antimicrobici e Resistenze) (2006) Active surveillance of Streptococcus pneumoniae bacteremia in Italian children. Vaccine 24(47-48):6938-6943

87. Torres JM, Cardenas O, Vasquez A, Schlossberg D (1998) Streptococcus pneumoniae bacteremia in a community hospital. Chest 113(2):387-390

88. Fujiwara T, Nakano K, Kawaguchi M, Ooshima T, Sobue S, Kawabata S, Nakagawa I, Hamada S (2001) Biochemical and genetic characterization of serologically untypable Streptococcus mutans strains isolated from patients with bacteremia. Eur J Oral Sci 109(5):330-334

89. Gassas A, Grant R, Richardson S, Dupuis LL, Doyle J, Allen U, Abla O, Sung L (2004) Predictors of viridans streptococcal shock syndrome in bacteremic children with cancer and stem-cell transplant recipients. J Clin Oncol 22(7):1222-1227

90. Pérez Solís D, Díaz Martín JJ, Suárez Menéndez E (2009) Neonatal retroauricular cellulitis as an indicator of group B streptococcal bacteremia: a case report. J Med Case Rep 3:9334

91. Palacio F, Lewis JS 2nd, Sadkowski L, Echevarria K, Jorgensen JH (2011) Breakthrough bacteremia and septic shock due to Streptococcus anginosus resistant to daptomycin in a patient receiving daptomycin therapy. Antimicrob Agents Chemother 55(7):3639-3640

92. Ko EY, Kang HJ, Kwon HJ, Choi UY, Lee JW, Lee DG, Park YJ, Chung NG, Cho B, Kim HK, Kang JH (2011) Clinical investigation of bacteremia in children with hemato-oncologic diseases. Infect Chemother 43(2):191-197

93. Vos FJ, Kullberg BJ, Sturm PD, Krabbe PF, van Dijk AP, Wanten GJ, Oyen WJ, Bleeker-Rovers CP (2012) Metastatic infectious disease and clinical outcome in Staphylococcus aureus and Streptococcus species bacteremia. Medicine (Baltimore) 91(2):86-94

94. Torroba L, Moreno S, Lorenzana L, Buzon L (1987) Purulent meningitis after percutaneous radiofrequency trigeminal rhizotomy. J Neurol Neurosurg Psychiatry 50(8):1081-1082

95. Cohen LF, Dunbar SA, Sirbasku DM, Clarridge JE 3rd (1997) Streptococcus bovis infection of the central nervous system: report of two cases and review. Clin Infect Dis 25(4):819-823

96. Ulug M, Ulug NC, Celen MK, Geyik MF, Ayaz C (2009) A case of meningitis caused by Streptococcus pyogenes in a previously healthy woman. J Infect Dev Ctries 3(3):241-244

97. Onoyama S, Ogata R, Wada A, Saito M, Okada K, Harada T (2009) Neonatal bacterial meningitis caused by Streptococcus gallolyticus subsp. pasteurianus. J Med Microbiol 58(Pt 9):1252-1254

98. Sturt AS, Yang L, Sandhu K, Pei Z, Cassai N, Blaser MJ (2010) Streptococcus gallolyticus subspecies pasteurianus (biotype II/2), a newly reported cause of adult meningitis. J Clin Microbiol 48(6):2247-2249

99. Lopez JP, Roque J, Torres J, Levin AV (2010) Severe retinal hemorrhages in infants with aggressive, fatal Streptococcus pneumoniae meningitis. J AAPOS 14(1):97-98

100. Eyre DW, Kenkre JS, Bowler IC, McBride SJ (2010) Streptococcus equi subspecies zooepidemicus meningitis - a case report and review of the literature. Eur J Clin Microbiol Infect Dis 29(12):1459-1463

101. Yamagishi Y, Mikamo H (2011) Case of meningitis caused by group B Streptococcus treated with high dose of meropenem. Jpn J Antibiot 64(4):239-246

102. Thigpen MC, Whitney CG, Messonnier NE, Zell ER, Lynfield R, Hadler JL, Harrison LH, Farley MM, Reingold A, Bennett NM, Craig AS, Schaffner W, Thomas A, Lewis MM, Scallan E, Schuchat A; Emerging Infections Programs Network (2011) Bacterial meningitis in the United States, 1998-2007. N Engl J Med 364(21):2016-2025 
103. Gouveia EL, Reis JN, Flannery B, Cordeiro SM, Lima JB, Pinheiro RM, Salgado K, Mascarenhas AV, Carvalho MG, Beall BW, Reis MG, Ko AI (2011) Clinical outcome of pneumococcal meningitis during the emergence of pencillin-resistant Streptococcus pneumoniae: an observational study. BMC Infect Dis 11:323

104. Nga TV, Nghia HD, Tu LT, Diep TS, Mai NT, Chau TT, Sinh DX, Phu NH, Nga TT, Chau NV, Campbell J, Hoa NT, Chinh NT, Hien TT, Farrar J, Schultsz C (2011) Real-time PCR for detection of Streptococcus suis serotype 2 in cerebrospinal fluid of human patients with meningitis. Diagn Microbiol Infect Dis 70(4):461-467

105. Klatte JM, Clarridge JE 3rd, Bratcher D, Selvarangan R (2012) A longitudinal case series description of meningitis due to Streptococcus gallolyticus subsp. pasteurianus in infants. J Clin Microbiol 50(1):57-60

106. Saito N, Hida A, Koide Y, Ooka T, Ichikawa Y, Shimizu J, Mukasa A, Nakatomi H, Hatakeyama S, Hayashi T, Tsuji S (2012) Culturenegative brain abscess with Streptococcus intermedius infection with diagnosis established by direct nucleotide sequence analysis of the 16s ribosomal RNA gene. Intern Med 51(2):211-216

107. Harrell T, Hammes JS (2012) Meningitis admitted to a military hospital: a retrospective case series. Mil Med 177(10):1223-1226

108. Dinani A, Ktaich N, Urban C, Rubin D (2009) Levofloxacinresistant-Streptococcus mitis endophthalmitis: a unique presentation of bacterial endocarditis. J Med Microbiol 58(Pt 10):1385-1387

109. Velez-Montoya R, Rascón-Vargas D, Mieler WF, Fromow-Guerra J, Morales-Cantón V (2010) Intravitreal ampicillin sodium for antibiotic-resistant endophthalmitis: Streptococcus uberis first human intraocular infection report. J Ophthalmol 2010. pii: 169739

110. Hauch A, Eliott D, Rao NA, Vasconcelos-Santos DV, O'Hearn T, Fawzi AA (2010) Dark hypopyon in Streptococcus bovis endogenous endophthalmitis: clinicopathologic correlations. J Ophthalmic Inflamm Infect 1(1):39-41, 230

111. Kaliamurthy J, Cuteri V, Jesudasen N, Salman A, Thomas PA, Preziuso S (2011) Post-operative ocular infection due to Streptococcus dysgalactiae subspecies equisimilis. J Infect Dev Ctries 5(10):742-744

112. Ying Q, Zhang J, Yang L, Ding J, Song X, Du W, Ma Y, Yu F (2012) Antimicrobial resistance, serotypes and genotypes of Streptococcus pneumoniae isolates associated with ocular infection in China. Afr J Microbiol Res 6(1):160-164

113. Goldberg RA, Flynn HW Jr, Miller D, Gonzalez S, Isom RF (2013) Streptococcus endophthalmitis outbreak after intravitreal injection of bevacizumab: one-year outcomes and investigative results. Ophthalmology Feb 28. pii: S0161-6420(12)01177-3

114. Shukla A, Abreu Z, Bargman JM (2006) Streptococcal PD peritonitis - a 10-year review of one centre's experience. Nephrol Dial Transplant 21(12):3545-3549

115. Hörner R, Salla A, Oliveira LO, Forno NL, Righi RA, Domingues VO, Rigatti F, Mayer LE (2010) Spontaneous bacterial peritonitis caused by Streptococcus bovis: case report and review of the literature. Braz J Infect Dis 14(3):294-296

116. de Los Santos CA, Prado Lima Figueiredo AE, Poli-de-Figueiredo CE (2010) Streptococcus agalactiae: a rare peritoneal infection in a continuous ambulatory peritoneal dialysis patient. Ren Fail 32(9):1123-1124

117. Legras A, Lodico R, Ferre R, Valleur P, Pautrat K (2011) Primary peritonitis due to Streptococcus A: laparoscopic treatment. J Visc Surg 148(4):e315-e317

118. Litarski A, Janczak D, Cianciara J, Merenda M (2011) Spontaneous bacterial peritonitis due to Streptococcus pneumoniae - case report. Pol Przegl Chir 83(5):283-286

119. Mizuno M, Ito Y, Masuda T, Toda S, Hiramatsu H, Suzuki Y, Ozaki T, Yasuda Y, Ito I, Tsuboi N, Sato W, Maruyama S, Imai E, Matsuo S (2011) A case of fulminant peritonitis caused by Streptococcus mitis in a patient on peritoneal dialysis. Intern Med 50(5):471-474
120. Cheung CY, Cheng NH, Chau KF, Li CS (2011) Streptococcus gordonii peritonitis in a patient on CAPD. Ren Fail 33(2):242-243

121. Yap DY, To KK, Yip TP, Lui SL, Chan TM, Lai KN, Lo WK (2012) Streptococcus bovis peritonitis complicating peritoneal dialysis - a review of 10 years' experience. Perit Dial Int 32(1):55-59

122. Demers C, Tremblay M, Lacourcière Y (1988) Acute vertebral osteomyelitis complicating Streptococcus sanguis endocarditis. Ann Rheum Dis 47(4):333-336

123. Asao K, Utsunomiya Y, Hirano K, Shike T, Imasawa T, Omura K, Tomonari H, Kawamura T, Kuriyama S, Sakai O (1995) Rhabdomyolysis associated with bacteremia due to Streptococcus viridans. Intern Med 34(8):785-789

124. Tinsa F, Siala N, Ncibi N, Fetni I, Kasdalli K, Ben Jballah N, Mehrezi A (2009) Pneumococcal infection and hemolytic uremic syndrome. Tunis Med 87(11):790-792

125. Aebi T, Weisser M, Bucher E, Hirsch HH, Marsch S, Siegemund M (2010) Co-infection of influenza B and streptococci causing severe pneumonia and septic shock in healthy women. BMC Infect Dis 10:308

126. Furitsch M, Träger K, van der Linden M, Spellerberg B (2011) Group A streptococcal vertebral osteomyelitis presenting with acute quadriplegia. Infection 39(4):389-391

127. Falcone EL, Hanses S, Stock F, Holland SM, Zelazny AM, Uzel G (2012) Streptococcal infections in patients with chronic granulomatous disease: case report and review of the literature. J Clin Immunol 32(4):649-652

128. Leyro J (2008) History of Streptococcus Pyogenes. COSMOS UCD - Cluster 7. Dr. LeFebvre

129. Nowosiad M, Giedrys-Kalemba S (2008) Zakażenia Streptococcus pneumoniae - aktualne problemy. Postepy Mikrobiol 3(47):331-338

130. Hardie JM, Whiley RA (1997) Classification and overview of the genera Streptococcus and Enterococcus. Soc Appl Bacteriol Symp Ser 26:1S-11S

121. Zbinden A, Mueller NJ, Tarr PE, Spröer C, Keller PM, Bloemberg GV (2012) Streptococcus tigurinus sp. nov., isolated from blood of patients with endocarditis, meningitis and spondylodiscitis. Int J Syst Evol Microbiol 62(Pt 12):2941-2945

132. Schlegel L, Grimont F, Ageron E, Grimont PA, Bouvet A (2003) Reappraisal of the taxonomy of the Streptococcus bovis/Streptococcus equinus complex and related species: description of Streptococcus gallolyticus subsp. gallolyticus subsp. nov., S. gallolyticus subsp. macedonicus subsp. nov. and $S$. gallolyticus subsp. pasteurianus subsp. nov. Int J Syst Evol Microbiol 53(Pt 3):631-645

133. Peltroche-Llacsahuanga H, Frye B, Haase G (2012) Isolation of Streptococcus urinalis from a human blood culture. J Med Microbiol 61(Pt 5):740-742

134. Willcox MD, Zhu H, Knox KW (2001) Streptococcus australis sp. nov., a novel oral streptococcus. Int J Syst Evol Microbiol 51(Pt 4):1277-1281

135. Héry-Arnaud G, Rouzic N, Doloy A, Le Lay G, Garré M, Payan C, Poyart C (2011) Streptococcus australis meningitis. J Med Microbiol 60(11):1701-1704

136. Jans C, Follador R, Hochstrasser M, Lacroix C, Meile L, Stevens MJ (2013) Comparative genome analysis of Streptococcus infantarius subsp. infantarius CJ18, an African fermented camel milk isolate with adaptations to dairy environment. BMC Genomics 14(1):200

137. Szczepańska J (2001) Prognozowanie występowania próchnicy $\mathrm{u}$ dzieci $\mathrm{w}$ oparciu o wieloaspektowa analize czynników ryzyka-część I. Nowa Stomatologia 4:3-11

138. Aligne CA, Moss ME, Auinger P, Weitzman M (2003) Association of pediatric dental caries with passive smoking. JAMA 289(10):1258-1264

139. Bagińska J (2004) Próchnica wczesna-problem nie tylko stomatologiczny. Nowa Stomatologia 3:128-132 
140. Li Y, Caufield PW, Dasanayake AP, Wiener HW, Vermund SH (2005) Mode of delivery and other maternal factors influence the acquisition of Streptococcus mutans in infants. J Dent Res 84(9):806-811

141. Szczepańska J, Szydłowska B, Lubowiedzka B, Pawłowska E (2007) Analiza czynników ryzyka występowania choroby próchnicowej u 3-letnich dzieci. Czas Stomatol 3:162-170, LX

142. American Academy on Pediatric Dentistry; American Academy of Pediatrics (2008-2009) Policy on early childhood caries (ECC): classifications, consequences, and preventive strategies. Pediatr Dent 30(7 Suppl):40-43

143. Fontana M, Young DA, Wolff MS (2009) Evidence-based caries, risk assessment, and treatment. Dent Clin North Am 53(1):149-161

144. Kishi M, Abe A, Kishi K, Ohara-Nemoto Y, Kimura S, Yonemitsu M (2009) Relationship of quantitative salivary levels of Streptococcus mutans and $S$. sobrinus in mothers to caries status and colonization of mutans streptococci in plaque in their 2.5-year-old children. Community Dent Oral Epidemiol 37(3):241-249
145. Nurelhuda NM, Al-Haroni M, Trovik TA, Bakken V (2010) Caries experience and quantification of Streptococcus mutans and Streptococcus sobrinus in saliva of Sudanese schoolchildren. Caries Res 44(4):402-407

146. Moser SA, Mitchell SC, Ruby JD, Momeni S, Osgood RC, Whiddon J, Childers NK (2010) Repetitive extragenic palindromic PCR for study of Streptococcus mutans diversity and transmission in human populations. J Clin Microbiol 48(2):599-602

147. Morou-Bermúdez E, Billings RJ, Burne RA, Elías-Boneta A (2011) Caries risk pyramid: a practical biological approach to caries management by risk assessment. P R Health Sci J 30(4):165-166

148. Minister Zdrowia (2010) Monitorowanie stanu zdrowia jamy ustnej populacji polskiej w latach 2010-2012. Program na lata 2010-2012

149. Czarkowski MP, Kondej B, Cielebąk E, Staszewska B (2012) Szczepienia ochronne w Polsce w 2011 roku. Rzeczpospolita Polska. s. 89 